\title{
Pendidikan Karakter melalui Pembentukan Bank Sampah Berbasis Pesantren di PP Ibnu Sina Genteng Banyuwangi
}

\author{
Nurul Inayah, Ribut Suprapto \\ IAIDA Darussalam Blokagung Banyuwangi \\ nurulinayah@yahoo.com
}

\begin{abstract}
ABSTRAK
Pemerintah daerah kabupaten Banyuwangi, yang telah mulai menggerakkan seluruh elemen masyarakat untuk peduli dengan sampah. Dinas kebersihan dan pertamanan (DKP) telah membentuk Bank sampah dengan menggerakkan Dasa Wisma (Dawis)yang ada di tiap-tiap kelurahan dan desa yang ada di kota Banyuwangi. Penanganan dan pengelolaan sampah yang benar sangat penting untuk dilakukan di Pondok Pesantren. Pondok Pesantren saat ini sudah seharusnya menjadi tempat untuk belajar tentang pengelolaan sampah yang benar, memulai membangun kesadaran akan penanganan dan pengelolaan sampah dengan membentuk bank sampah berbasis pesantren. Tujuan dari pengabdian ini adalah untuk: (1) Untuk mendeskripsikan proses kegiatan belajar mengajar yang ada di SMK Ibnu Sina yang berada di PP Ibnu Sina. (2) Untuk melihat Kepedulian siswa di SMK Ibnu Sina yang berada di PP Ibnu Sina tentang kebersihan lingkungan. (3) Memberikan pelatihan pengelolaan sampah, dan dilanjutkan membentuk bank sampah, diharapkan akan menciptakan lingkungan sehat dan bersih. Kegiatan sosialisasi telah dilaksanakan pada tanggal 23 Nopember 2016, dan Pelaksanaan Kegiatan Pelatihan pengelolaan sampah organik dan Pelatihan pengolahan sampah non organik, dilaksanakan pada tanggal 14 Desember 2016. Selanjutnya juga telah dibentuk kader untuk dapat melanjutkan perintisan pendirian bank sampah. Dan dikarenakan keterbatasan waktu dan dana maka untuk menindaklanjuti kegiatan pengabdian tersebut akan dilanjutkan oleh Bank Sampah Darussalam Blokagung Banyuwangi, di bawah pengawasan dan koordinasi Lembaga Penelitian dan Pengabdian Kepada Masyarakat Institut Agama Islam Darussalam Blokagung Banyuwangi.
\end{abstract}

Kata Kunci : Pendidikan inovatif, kreatifitas, bank sampah, Pesantren, pengelolaan sampah

\section{LATAR BELAKANG}

Pemerintah telah membuat kebijakan dengan menerbitkan Peraturan Pemerintah Republik Indonesia Nomor 81 Tahun 2012 Tentang Pengelolaan Sampah Rumah Tangga Dan Sampah Sejenis Sampah Rumah Tangga ${ }^{1}$. Dimana di dalam Peraturan Pemerintah ini meliputi pengaturan tentang: a. kebijakan dan strategi pengelolaan sampah; b. penyelenggaraan pengelolaan sampah; c. kompensasi; d. pengembangan dan penerapan teknologi; e. sistem informasi; f. peran masyarakat; dan g. pembinaan. ${ }^{2}$

\footnotetext{
${ }^{1}$ Muh. Barid Nizarudin Wajdi, "Nyadranan, Bentuk Akulturasi Islam Dengan Budaya Jawa (Fenomena Sosial Keagamaan Nyadranan Di Daerah Baron Kabupaten Nganjuk)," JURNAL LENTERA : Kajian Keagamaan, Keilmuan dan Teknologi 3, no. 2 (October 13, 2017), accessed October 21, 2017, http://www.ejournal.staimnglawak.ac.id/index.php/lentera/article/view/60.

${ }_{2}$ Peraturan Pemerintah Republik Indonesia Nomor 81 Tahun 2012 Tentang Pengelolaan Sampah Rumah Tangga Dan Sampah Sejenis Sampah Rumah Tangga
} 
Pada poin $\mathrm{f}$. Tentang peran masyarakat di sebutkan bahwa Masyarakat berperan serta dalam proses pengambilan keputusan, penyelenggaraan, dan pengawasan dalam kegiatan pengelolaan sampah rumah tangga dan sampah sejenis sampah rumah tangga yang diselenggarakan oleh Pemerintah dan/atau pemerintah daerah.

Seperti di pemerintah daerah kabupaten Banyuwangi, yang telah mulai menggerakkan seluruh elemen masyarakat untuk peduli dengan sampah. Dinas kebersihan dan pertamanan (DKP) telah membentuk Bank sampah dengan menggerakkan Dasa Wisma (Dawis) yang ada di tiap-tiap kelurahan dan desa yang ada di kota Banyuwangi.

Bank sampah adalah sebuah yayasan yang awalnya dibina di daerah Yogyakarta, dan kini sudah diadopsi di kota-kota seluruh Indonesia. ${ }^{3}$ Bank sampah adalah strategi untuk membangun kepedulian masyarakat agar dapat „,berkawan dengan sampah untuk mendapatkan manfaat ekonomi langsung dari sampah. Jadi, bank sampah tidak dapat berdiri sendiri melainkan harus diintegrasikan dengan gerakan 4R yaitu : a. Reduce (mengurangi), b. Reuse (menggunakan kembali), c. Recycle (mendaur ulang), d. Replace (mengganti), ${ }^{4}$ sehingga manfaat langsung yang dirasakan tidak hanya ekonomi, namun pembangunan lingkungan yang bersih, hijau, dan sehat.

Tujuan didirikannya bank sampah tentu saja menerima penyimpanan sampah dari masyarakat sekitar, dan menjadikan sampah tersebut uang. Bank sampah juga bertujuan menjaga lingkungan, sisanya agar masyarakat mampu memberdayakan barang bekas menjadi sesuatu yang bisa dijadikan uang. Kinerjanya lebih pada sampah di sekitar lingkungan masyarakat dipilah-pilah, lantas ditimbang dan kemudian dihargai. ${ }^{5}$

Melihat begitu bermanfaatnya program Bank sampah ini, semestinya program ini sudah menjadi andalan untuk dikembangkan pada masyarakat luas ${ }^{6}$.

Pesantren selama ini masih dianggap oleh masyarakat sebagai tempat yang kumuh, kotor dan tidak sehat. Hidup bersama dalam komunitas berjamaah dengan fasilitas yang terbatas, juga dapat memunculkan kebiasaan-kebiasaan yang kurang sehat, mandi dikolam bersama, buang sampah sembarangan, dan sebagainya.

Dalam kehidupan keseharian setiap santri, jika diasumsikan membeli jajanan yang berkemasan plastik 2 bungkus, dan jika jumlah santri 300 maka dapa terproduksi 600 bungkus plastik, jika terkumpul dalam seminggu saja, berapa sampah yang kumpul ?

Penanganan dan pengelolaan sampah yang benar sangat penting untuk dilakukan di Pondok Pesantren. Pondok Pesantren saat ini sudah seharusnya menjadi tempat untuk belajar tentang pengelolaan sampah yang benar, memulai membangun kesadaran akan penanganan dan pengelolaan sampah dengan membentuk bank sampah berbasis pesantren.

Dari survey yang telah dilakukan, PP Ibnu Sina dengan jumlah santri yang lebih dari 373, tepatnya di yayasan PP Ibnu Sina memiliki 373 siswa yang diantaranya menjadi santri mukim 200 santri sisanya adalah siswa yang tinggal dirumah masing-masing. Dan mereka belum memiliki kesadaran untuk peduli dengan sampah. Sebenarnya Pelatihan pengolahan sampah sudah pernah dilakukan namun belum menyelesaikan masalah. Perilaku yang tidak peduli dengan keberadaan sampah akan dapat merugikan, terutama akan mendatangkan penyakit yang selanjutnya mengganggu aktivitas belajar santri.

Santri yang berada di PP Ibnu Sina belum memiliki kesadaran untuk peduli dengan sampah. Maka dalam artikel ini nantinya akan membahas tentang : Bagaimana proses kegiatan

\footnotetext{
${ }^{3}$ Nurul Purbasari,Skripsi, Pemberdayaan Masyarakat Melalui Kegiatan Daur Ulang Sampah Plastik (Studi Kasus Pada Komunitas Bank Sampah POKLILI Perumahan Griya Lembah Depok Kecamatan Sukmajaya Kota Depok), 2014, h.21-22 ${ }^{4}$ ibid

${ }^{5}$ Bambang Wintoko, Panduan Praktis Mendirikan Bank Sampah, (Yogyakarta: Pustaka Baru Press) cet-1, h. 58.

${ }^{6} \mathrm{M}$ Barid Nizarudin Wajdi, "HARMONISASI NILAI PENDIDIKAN ISLAM DENGAN KEARIFAN BUDAYA LOKAL,” Jurnal Studi Islam: Pancawahana 11, no. 1 (2016): 51-78.
} 
belajar mengajar yang ada di SMK Ibnu Sina ?, Bagaimana Kepedulian siswa tentang kebersihan lingkungan?

\section{PEMBAHASAN}

\section{Gambaran Umum Lokasi}

Pondok Pesantren Ibnu Sina Genteng Banyuwangi merupakan lembaga pendidikan pesantren yang berada di daerah Banyuwangi Selatan wilayah Provinsi Jawa Timur, tepatnya kota Genteng yang berjarak $\pm 45 \mathrm{KM}$ dari kota Kabupaten Banyuwangi. Adapun pesantren Ibnu Sina secara resmi berbadan hukum dan berbentuk yayasan dengan nama "Yayasan Pondok Pesantren Ibnu Sina" dengan akte notaris Soesanto Adi Purnomo, SH. Nomor 31 tahun 2010. Pondok Pesantren IBNU SINA Genteng di Asuh oleh Drs. KH. Masykur Ali mendirikan Sekolah Menengah Kejuruan berbasis pesantren. Yaitu SMK IBNU SINA yang berdiri 9 Juni tahun 2013. Pada awal pendirianya SMK Ibnu Sina hanya 2 jurusan yaitu teknik komputer dan perbankan syariah dengan jumlah siswa di tahun awal 40 siswa, selanjutnya disusul jurusan Geologi Pertambangan, selanjutnya Teknik Sepeda Motor dan terakhir jurusan Teknik Pengolahan Hasil Pertanian. Dan saat ini jumlah keseluruhan siswa 373 siswa. SMK Ibnu Sina masih dalam tahap terus membangun, menambah kelas, dan menambah lahan bangunan.

\section{Kegiatan Belajar Di SMK Ibnu Sina}

Kegiatan belajar di SMK Ibnu Sina dimulai pada jam 06.30 dengan diawali sholat Dhuha dua rekaat bersama yang dilaksanakan di halaman sekolah, dilanjutkan dengan tausiah dan wejangan yang disampaikan oleh kepala sekolah. Tujuan kegiatan sholat dhuha bersama dengan dilanjutkan dengan tausiah merupakan pendidikan karakter yang ditanamkan pada seluruh siswa. Selanjutnya kegiatan belajar dilanjutkan didalam kelas sesuai dengan penjurusannya. Di jam 11.15 siswa di ajak untuk sholat dhuhur berjama'ah, dihalaman sekolah. Dan setelah selesai sholat dhuhur berjama'ah, kegiatan belajar di kelas dilanjutkan sampai dengan jam 13.30 WIB. Pada hari Senin sampai dengan Kamis dan Sabtu. Namun jadwal kegiatan belajar mengajar disekolah akan berubah pada hari Jum'at. Dimana pada hari Jum'at sholat Dhuha berjama'ah dilanjutkan dengan tausiyah yang diperpanjang dua jam mata pelajaran akan diisi dengan materi tentang kependidikan karakter yang menekankan pada pendidikan kebangsaan. Selain itu pendidikan karakter juga akan ditekankan lagi oleh para guru yang mengajar dikelas.

Kegiatan extrakulikuler di SMK Ibnu Sina yang ada adalah pramuka, dan olah raga, yaitu : PMR (Palang Merah Remaja), Pramuka, Olah Raga (Voly Ball, Badminton, tenes lantai, basket) English Club, Seni Kaligrafi, Desain Grafis dan jurnalistik. Dan jadwal kegiatan extrakulikuler tersebut diluar jam belajar siswa, dan hari Minggu.

Prestasi yang mengesankan adalah yang pernah diraih adalah juara 3 Hidroponik yang diselenggarakan oleh Universitas 17 Agustus Banyuwangi pada acara perayaan Kemerdekaan Republik Indonesia pada bulan Agustus 2016, dari jurusan Teknologi Hasil Pertanian.

Secara keseluruhan perilaku kebersihan daripada siswa SMK ibnu Sina masih kurang disiplin dalam hal pembuangan sampah. Masih banyak siswa-siswa yang membuang sampah sembarangan dan tidak pada tempatnya, apalagi di dalam kelas ada tempat sampah. Tempat sampah hanya ada di luar kelas/dihalaman. Namun ditiap-tiap kelas sebenarnya telah dibentuk piket kelas yang bertugas untuk kebesihan kelas.

Penanganan dan pengelolaan sampah yang benar saat ini sudah sangat penting untuk 
dilakukan. Pondok Pesantren saat ini sudah seharusnya menjadi tempat untuk belajar tentang pengelolaan sampah yang benar, dengan memulai membangun kesadaran akan penanganan dan pengelolaan sampah.

Penanganan dan pengelolaan sampah sebenarnya sudah dimulai oleh PP Ibnu Sina beberapa kali pihak yayasan sudah bekerja sama dengan LSM Merdeka Dari Sampah Banyuwangi untuk pelatihan pemilahan sampah rumah tangga yang dihasilkan oleh santri. Namun pelatihan yang telah dilakukan tersebut tidak mampu menyelesaikan masalah, pelatihan pemilahan sampah hanya diberikan kepada santri 1 kali, belum ada tindak lanjut untuk bisa memberdayakan santri. Karena bagaimanapun juga penyelesaian masalah sampah harus mampu melibatkan dan memberdayakan santri secara menyeluruh terkait dengan, pembatasan timbunan sampah, pengumpulan sampah, pemilahan sampah, memanfaatan sekaligus mendaurulangan sampah secara berkelanjutan.

\section{Pembentukan Bank Sampah}

Model Pembentukan Bank Sampah ini dengan pemberdayaan secara "riil" kepada komunitas santri yang juga siswa, yang berada di PP Ibnu Sina dengan pelatihan dan pendampingan bersama stakeholders yang telah berhasil mengembangkan konsep pemanfaatan sampah secara maksimal dengan pelatihan pengelolaan sampah dan pembentukan Bank Sampah.

\section{Berkoordinasi dengan pihak Yayasan PP Ibnu Sina;}

Koordinasi ini diperlukan untuk mempersiapkan segala kebutuhan yang terkait dengan pembentukan bank sampah sekaligus menyiapkan santri yang akan dijadikan kader untuk dilatih dalam pengelolaan bank sampah.

Pada tahap ini sudah dilakukan mulai pada tanggal 24 Oktober 2016 dengan menemui ketua yayasan PP Ibnu Sina KH. Maskur Ali. Dalam kesempatan tersebut juga untuk pengambilan data awal, seperti jumlah, santri dan siswa, visi misi sekolah, struktur organisasi, rombongan belajar, serta jumlah guru.

2. Sosialisasi dan pelatihan manajemen pengelolaan bank sampah dan Pelatihan pengelolaan sampah organik dan non organik;

Dalam pembentukan bank sampah diperlukan 2 tahap pelatihan yaitu pelatihan pengelolaan sampah dan manajemen pengelolaan bank sampah. Tahap pertama adalah sosialisasi dan Pelatihan manajemen pengelolaan bank sampah ini nantinya akan disampaikan oleh Dinas Kebersihan dan Pertamanan Kabupaten Banyuwangi. Sedangkan pelatihan tahap kedua pelatihan pengelolaan sampah organik dan sampah non organik akan disampaikan oleh LSM Merdeka Dari Sampah Kabupaten Banyuwangi.

\section{Proses Pelaksanaan Pelatihan}

Pada proses pelaksanaan pelatihan akan dibagi beberapa tahap, tahapannya adalah :

\section{a). Sosialisasi pengelolaan sampah dan Bank Sampah disekolah.}

Kegiatan ini telah dilaksanakan pada tanggal 23 Nopember 2016, yang dihadiri oleh 130 siswa-siswi dari SMK Ibnu sina yang berasal dari 5 jurusan yaitu :

Geologi Pertambangan, Perbankan Syariah, Teknik Komputer Dan Jaringan, Teknik Sepeda Motor, Teknik Pengolahan Hasil Pertanian.

Acara dimulai pada jam 13.00 WIB dan berakhir pada jam 15.00 WIB. Pada saat sosialisasi materi yang diberikan adalah tentang pencemaran lingkungan, dan 
pembentukan bank sampah di sekolah.

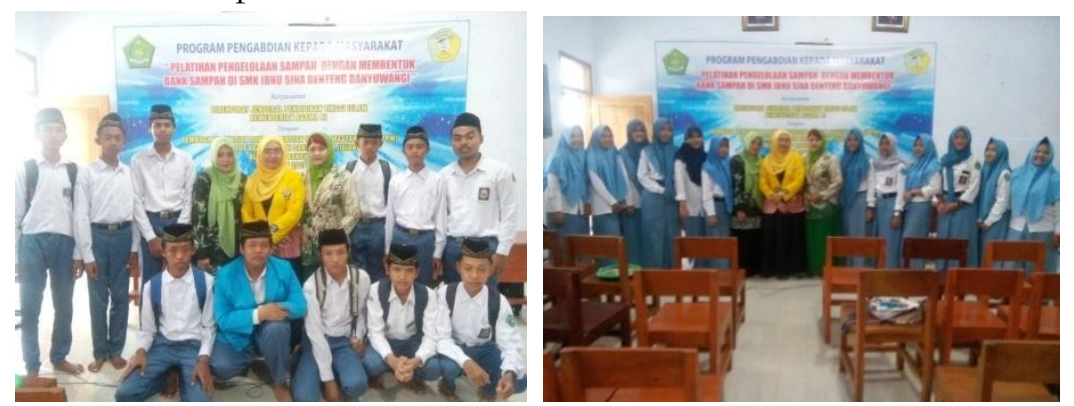

Gambar 1. Peserta Sosialisasi dan Pelatihan Pengelolaan Sampah Melalui Pembentukan Bank Sampah di SMK Ibnu Sina

b). Pelatihan pengelolaan sampah organik dengan pembuatan pupuk kompos dari sampah rumah tangga dan sampah non organik.

Pelaksanaan Kegiatan Pelatihan pengelolaan sampah organik dan Pelatihan pengolahan sampah non organik, dilaksanakan pada tanggal 14 Desember 2016. Pada jam 09.00 di lahan praktek Teknik Pengolahan Hasil Pertanian yang diikuti sejumlah 50 orang siswa dan siswi. Pelatihan pengelolaan sampah organik dengan pembuatan pupuk organik di berikan pada siswa putra, sedangkan pelatihan sampah non organik diberikan pada siswa putri, dengan nara sumber sebagai berikut :

\section{Pelatih pengolahan sampah organik :}

Bapak Ramang Rameli Rakasiwi dari lembaga MASKOT Pengabdi Lingkungan dengan alamat kantor Jln. Tiga Berlian Kmp. Ujung Banyuwangi.

Selanjutnya pelatihan pengelolaan sampah organik dengan membuat kompos dari sampah dapur rumah tangga.
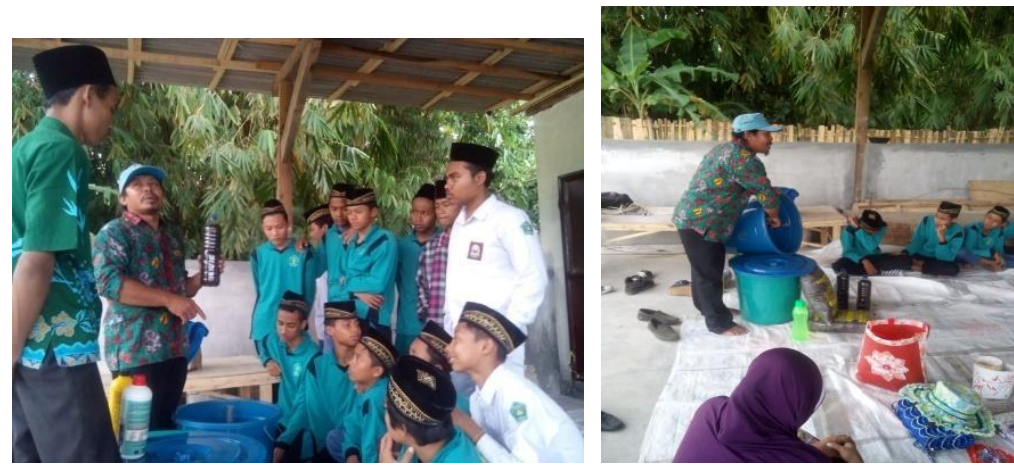

Gambar. Proses Buatan Pupuk kompos

\section{Pelatih pengolahan sampah non organik :}

Ibu Siti Rokhanah Dari Dasa Wisma (Dawis) Anggur Perum Kalirejo Kecamatan Kabat Banyuwangi. Pada pelatihan pengolahan sampah non organik siswi diajari untuk membuat tas dari bekas gelas air minum kemasan, bros, kipas, dan sebagainya. 


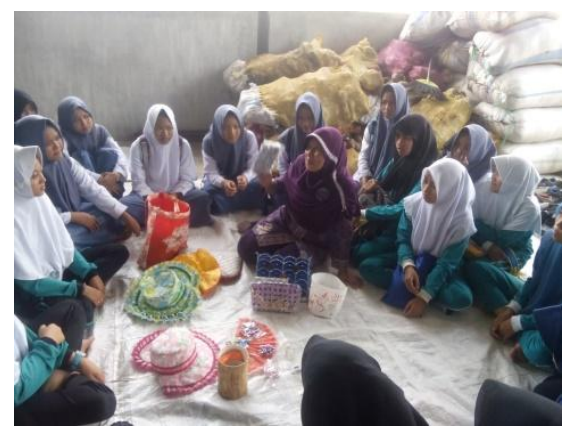

Gambar. Proses Pembuatan kerajinan dari sampah non organik

\section{c). Menyiapkan tempat untuk dijadikan kantor bank sampah;}

Diperlukan tempat khusus untuk dijadikan kantor administrasi pencatatan dan pengumpulan sampah dari nasabah nantinya.

Rencana tempat yang akan digunakan sebagai tempat perintisan bank sampah di SMP Ibnu Sina adalah di tempat yang saat ini masih digunakan untuk kantin.

\section{d). Pembentukan bank sampah dan Kaderisasi;}

Setelah pelatihan pengelolaan manajemen bank sampah dan pengelolaan sampah organik dan non organik maka dilanjutkan dengan mempersiapkan kader-kader untuk membentuk kepengurusan dan selanjutnya melaksanakan operasional bank sampah. Selanjutnya mempersiapkan kader-kader yang nantinya akan mengambil alih tugas pendampingan setelah program berakhir. Pendampingan pada kader-kader yang telah dilatih akan memastikan untuk keberhasilan berjalannya pemberdayaan tersebut. Pembentukan kader-kader dilakukan pada tanggal 17 Desember 2016. Dikediaman dari Bapak Muhammad Nasih, S.Pd.I. pada pertemuan tersebut membentuk kader-kader yang akan membentuk bank sampah SMK Ibnu Sina. Selanjutnya menyusun struktur organisasi dan menyiapkan kebutuhan instrumen bank sampah. Dan nama-nama yang akan dijadikan kader adalah sebagai berikut :

Siswa Putra

1. M Alfian Khoiruman

2. Moh. Miftah

3. M. David Qomaruz Z.

4. M. Bagus Prasetyo

5. Ahmad Riszki Adriyan
Siswi Putri

1. Arum Wahdah

2. Aulia Alfi Nurjanah

3. Fitri Bunga

4. Riska Rahmawati

5. Nuri Vina

Dan siswa-siswi yang menjadi kader juga sekaligus menjadi pengurus Bank Sampah SMK Ibnu Sina

\section{Struktur Organisasi}

\section{Bank Sampah SMK Ibnu Sina}

Penasehat

Penanggungjawab

Direktur

Wakil

Teller 1
: Muhammad Nasih, S.Pd.I

: Teguh Hariyanto, SE

: M Alfian Khoiruman

: M. Bagus Prasetyto

: Ahmad Riski Ardiyan 
Teller 2

Custumer Servise 1

Custumer Servise 2

Koordinator Pemilahan Sampah

Koordinator Kreatifitas

Instrumen Bank Sampah :

1. Buku Rekening

2. Slip Setoran

3. Timbangan

4. Tabel Tabungan Sampah

5. Buku Induk Tabunngan Sampah
: Arum Wahdah

: Riska Rahmawati

: Aulia Alfi Nurjanah

: Moh. Miftah

M. David Qomaruz Z.

: Nuri Vina

Fitri Bunga

\section{Pendampingan dan evaluasi indikator keberhasilan dalam peningkatan mutu} komunitas berbasis pesantren;

Dalam Penguatan Penyelenggaraan Pendidikan Inovatif Dan Kreatifitas Santri Melalui Pembentukan Bank Sampah Berbasis Pesantren Di PP Ibnu Sina yang pembentukan bank sampahnya diserahkan pengelolaannya pada SMK Ibnu Sina diharapkan setelah pelatihan dan aplikasi akan menyelesaikan permasalahan sampah yang ada di Pesantren dan para santri semakin memiliki kesadaran akan lingkungan yang bersih, juga akan menambah kreatifitas serta inovatif dalam pengelolaan sampah.

Pada proses pendampingan yang akan dilaksanakan diupayakan dari LPPM IAIDA akan melakukan kerjasama dengan menjadikan SMK Ibnu Sina sebagai sekolah dampingan dari kegiatan pengabdian LPPM IAIDA.

\section{Pemahaman santri akan sampah dan cara pengelolaannya}

Pada saat sosialisasi dan pelatihan siswa-siswi yang mengikuti kegiatan diberikan pertanyaan-pertanyaan yang harus dijawab oleh siswa siswi. Pertanyaan : pertama apa yang di ketahui tentang sampah ?.

Mereka menjawab, bahwa siswa-siswi memahami apa saja yang menjadi sampah dikehidupan mereka sehari-hari seperti : Barang sisa yang tidak lagi digunakan, barang kotor yang dibuang, kotoran, limbah manusia, sisa pembuangan, limbah pabrik, barang yang tidak layak disimpan, benda bekas yang tidak digunakan lagi, benda yang sudah dipakai, kotoran yang menyebabkan penyakit dan menganggap sampah menjadi penyebab erosi. Selanjutnya siswa memahami macam-macam sampah yang mereka sebut sebagai :

- sampah organik dan

- sampah nonorganik

siswa menganggap bahwa sampah berasal dari : aktifitas manusia/mahkluk hidup, dikehidupan sehari-hari, limbah, dari manusia yang tidak bertanggungjawab, sisa aktifitas manusia, lingkungan rumah, kantor. Dan siswa memetakan bahwa sampah terdapat disemua tempat, dirumah, di sekolah, dikantor, jalanan, sungai, tempat wisata, pingir jalan, tempat 
sampah, pasar, belakang rumah, selokan, dan sebagainya.

Dan perilaku siswa saat diberi pertanyaan, jika menemui sampah, apa yang akan dilakukan, maka mereka menjawab, ada yang bersedia mengambil dan membuangnya ditempat sampah dan ada yang mau untuk mengolahnya dan selanjutnya dijual. Namun ada siswa yang menjawab jika menemukan sampah dimanapun tempatnya maka akan dibakarnya, karena lebih praktis. Ada beberapa siswa yang akan membiarkan dan mengabaikan sampah yang ada disekitarnya dan ada jawaban jika menemukan sampah maka akan membuangnya kesungai. Inilah jawaban-jawaban siswa saat mereka belum mendapatkan sosialisasi tentang kebersihan lingkungan disekolah dan pencemaran lingkungan.

Dan setelah mereka mendapatkan sosialisasi serta pelatihan, maka seluruh siswa menganggap bahwa sampah merupakan sesuatu yang berharga yang dapat dimanfaatkan, terutama sampah organik yang dapat dibuat pupuk kompos, dan sampah plastik yang dapat dibuat kerajinan tangan. Dan dari semua siswa yang mengikuti sosialisasi dan pelatihan akan bersedia untuk mengkampanyekan lingkungan bersih dilingkungan mereka tinggal.

\section{Teori Yang Dihasilkan Dari Pendampingan Komunitas}

\section{a. Proses Pembelajaran}

Pendampingan yang telah dilakukan adalah pendampingan riel yang langsung pada sekolah yang berbasis Pondok Pesantren, dimana SMK Ibnu Sina merupakan sekolah yang berada dibawah naungan Pondok Pesantren Ibnu Sina Genteng Banyuwangi. Pada pendampingan ini sebenarnya bertujuan jangka panjang untuk proses pembelajaran siswa tentang kebersihan lingkungan serta kreatifitas yang bisa dihasilkan dari sampah. Proses pembelajaran yang dilakukan adalah dengan metode Pendekatan Kontekstual.

Pendekatan konstekstual berlatar belakang bahwa siswa belajar lebih bermakna dengan melalui kegiatan pembelajaran dengan mengalami sendiri dalam lingkungan alamiah, tidak hanya sekedar mengetahui, mengingat, dan memahami sesuatu. Pembelajaran kontekstual tidak hanya berorientasi target penguasaan materi saja, yang bisa jadi gagal dalam membekali siswa untuk memecahkan masalah dalam kehidupannya. Dengan demikian proses pembelajaran lebih diutamakan daripada hasil belajar, sehingga guru dituntut untuk merencanakan strategi pembelajaran yang variatif kreatif dengan prinsip-prinsip membelajarkan atau memberdayakan siswa, bukan mengajar siswa .

Borko dan Putnam mengemukakan bahwa dalam pembelajaran kontekstual, seorang guru harus memilih konteks pembelajaran yang tepat bagi siswa dengan cara mengaitkan pembelajaran dengan kehidupan nyata dan lingkungan di mana anak hidup dan berada serta dengan budaya yang berlaku dalam masyarakatnya. Pemahaman, penyajian ilmu pengetahuan, keterampilan, nilai dan sikap yang ada dalam materi dikaitkan dengan apa yang dipelajari dalam kelas dan dengan kehidupan sehari-hari ${ }^{8}$.

Dalam proses pembelajaran dengan mengajak siswa turut langsung dengan

7 (http://smacepiring.wordpress.com/2008/02/19/pendekatan-dan-metode-pembelajaran/). Diakses pada tanggal 7 januari 2017.

8 Depdiknas. (2002). Pengembangan Pelaksanaan Broad-Based Education, High-Based Education, dan Life Skills di SMU. Jakarta: Depdiknas.hlm.8

Volume 1, Number 1, Mei 2017| 21

Pendidikan Karakter melalui Pembentukan Bank Sampah Berbasis Pesantren di PP Ibnu Sina Genteng 
mengaplikasikan serta menjalankan kegiatan seperti membuang sampah di tempatnya, mengumpulkan, kemudian membawanya ke bank sampah selanjutnya memilah dan membuat sesuatu yang bermanfaat dari sampah yang ada, akan menjadikan siswa belajar efektif tentang kebersihan lingkungannya serta akan memunculkan kreatifitas siswa.

Penggunaan pembelajaran kontekstual memiliki potensi tidak hanya untuk mengembangkan ranah pengetahuan dan keterampilan proses, tetapi juga untuk mengembangkan sikap, nilai, serta kreativitas siswa dalam memecahkan masalah yang terkait dengan kehidupan mereka sehari-hari melalui interaksi dengan sesama teman, misalnya melalui pembelajaran kooperatif, sehingga juga mengembangkan ketrampilan sosial (social skills).

\section{b. Pendidikan Karakter}

Dengan sosialisasi dan pelatihan pengolahan sampah dilanjutkan dengan membentuk bank sampah di SMK Ibnu Sina, ini merupakan salah satu pendidikan karakter yang akan ditanamkan pada siswa tentang perilaku mencintai lingkungan bersih, serta kedisiplinan dalam membuang sampah ditempatnya.

Karakter menurut Hurlock yaitu keselarasan individu dengan pola-pola kelompok sosial tempat individu itu hidup sebagai hasil dari kontrol hati nurani terhadap tingkah laku individu. Dan komponen-komponen karakter menurut Hurlock yaitu antara lain aspek kepribadian, standar moral, pertimbangan nilai, upaya dan keinginan individu, hati nurani, pola-pola kelompok, dan tingkah laku individu dan kelompok. ${ }^{10}$ Jadi, karakter berasal dari nilai tentang sesuatu. Suatu nilai yang diwujudkan dalam bentuk perilaku anak itulah yang disebut karakter. Dapat dikatakan bahwa suatu krakter melekat dengan nilai dari perilaku tersebut, sehingga tidak ada perilaku yang tidak bebas dari nilai ${ }^{11}$.

Karakter yang kuat dibentuk oleh penanaman nilai yang menekankan tentang baik dan buruk. Nilai ini dibangun melalui penghayatan dan pengalaman, membangkitkan rasa ingin yang sangat kuat dan bukan menyibukkan diri dengan pengetahuan. ${ }^{12}$ Karakter merupakan istilah yang menunjuk pada aplikasi nilai-nilai kebaikan dalam bentuk tingkah laku. Walaupun istilah karakter dapat menunjuk kepada karakter baik dan karakter buruk, namun dalam aplikasinya orang dikatakan berkarakter jika mengaplikasikan nilai-nilai kebaikan dalam perilakunya. ${ }^{13}$

Dengan demikian dapat dipahami bahwa karakter merupakan suatu nilai-nilai yang tertanam dalam diri seseorang melalui pendidikan dan pengalaman yang menjadi satu nilai intrinsik yang melandasi sikap dan perilakunya. Karakter berarti tabiat atau kepribadian seseorang. Dengan memberikan pelatihan dan selanjutnya membentuk bank sampah di SMK Ibnu Sina diharapkan memiliki karakter mencintai lingkungan bersih selanjutnya juga memiliki rasa cinta terhadap negara Republik Indonesia.

Dan jika mengacu pada pendapat yang disampaikan oleh Zainal dan Sujak menyatakan

9 Depdiknas. (2002). Pengembangan Pelaksanaan Broad-Based Education, High-Based Education, dan Life Skills di SMU. Jakarta: Depdiknas.hlm.6

${ }^{10}$ Dharma Kesuma, dkk., Pendidikan Karakter: Kajian Teori dan Praktik di Sekolah, (Bandung: Remaja Rosdakarya, 2011), hlm. 29.

${ }^{11}$ Dharma Kesuma, dkk., Pendidikan Karakter: Kajian Teori dan Praktik di Sekolah, hlm. 11.

${ }^{12}$ Mohammad Fauzi Adhim, Postitive Parenting: Cara-cara Islami Mengembangkan Karakter Positif pada Anak Anda, (Bandung: Mizana, 2006), hlm., 272.

${ }^{13}$ Euis Sunarti, Menggali Kekuatan Cinta, (Jakarta: Elex Media Komputindo, 2005), hlm., 1.

Volume 1, Number 1, Mei 2017| 22

Pendidikan Karakter melalui Pembentukan Bank Sampah Berbasis Pesantren di PP Ibnu Sina Genteng 
karakter mengacu pada serangkaian sikap (attitudes), perilaku (bahaviors), motivasi (motivation), dan keterampilan (skills). Karakter dari bahasa Yunani yang berarti "to mark" atau menandai dan memfokuskan bagaimana mengaplikasikan nilai kebaikan dalam bentuk tindakan atau tingkah laku. ${ }^{14}$. Maka untuk menanamkan karakter diperlukan konsistensi dalam pelaksanaan, artinya perlu adanya pembiasaan yang kontinyu, terus-menerus.

\section{Diskusi Data}

\section{a. Kondisi Dampingan}

Kegiatan belajar di SMK Ibnu Sina dimulai pada jam 06.30 dengan diawali sholat Dhuha dua rekaat bersama yang dilaksanakan di halaman sekolah, dilanjutkan dengan tausiah dan wejangan yang disampaikan oleh kepala sekolah. Tujuan kegiatan sholat dhuha bersama dengan dilanjutkan dengan tausiah merupakan pendidikan karakter yang ditanamkan pada seluruh siswa. Selanjutnya kegiatan belajar dilanjutkan didalam kelas sesuai dengan penjurusannya. Di jam 11.15 siswa di ajak untuk sholat dhuhur berjama'ah, dihalaman sekolah. Dan setelah selesai sholat dhuhur berjama'ah, kegiatan belajar di kelas dilanjutkan sampai dengan jam 13.30 WIB. Pada hari Senin sampai dengan Kamis dan Sabtu. Namun jadwal kegiatan belajar mengajar disekolah akan berubah pada hari Jum'at. Dimana pada hari Jum'at sholat Dhuha berjama'ah dilanjutkan dengan tausiyah yang diperpanjang dua jam mata pelajaran akan diisi dengan materi tentang kependidikan karakter yang menekankan pada pendidikan kebangsaan. Selain itu pendidikan karakter juga akan ditekankan lagi oleh para guru yang mengajar dikelas.

Kegiatan extrakulikuler di SMK Ibnu Sina yang ada adalah pramuka, dan olah raga, yaitu : PMR (Palang Merah Remaja), Pramuka, Olah Raga (Voly Ball, Badminton, tenes lantai, basket) English Club, Seni Kaligrafi, Desain Grafis dan jurnalistik. Dan jadwal kegiatan extrakulikuler tersebut diluar jam belajar siswa, dan hari Minggu.

Prestasi yang mengesankan adalah yang pernah diraih adalah juara 3 Hidroponik yang diselenggarakan oleh Universitas 17 Agustus Banyuwangi pada acara perayaan Kemerdekaan Republik Indonesia pada bulan Agustus 2016, dari jurusan Teknologi Hasil Pertanian.

\section{b. Membangun karakter bersih}

Secara keseluruhan perilaku kebersihan daripada siswa SMK ibnu Sina masih kurang disiplin dalam hal pembuangan sampah. Masih banyak siswa-siswa yang membuang sampah sembarangan dan tidak pada tempatnya, apalagi di dalam kelas ada tempat sampah. Tempat sampah hanya ada di luar kelas/dihalaman. Namun ditiap-tiap kelas sebenarnya telah dibentuk piket kelas yang bertugas untuk kebesihan kelas.

Penanganan dan pengelolaan sampah sebenarnya sudah dimulai oleh PP Ibnu Sina beberapa kali pihak yayasan sudah bekerja sama dengan LSM Merdeka Dari Sampah Banyuwangi untuk pelatihan pemilahan sampah rumah tangga yang dihasilkan oleh santri. Namun pelatihan yang telah dilakukan tersebut tidak mampu menyelesaikan masalah, pelatihan pemilahan sampah hanya diberikan kepada santri 1 kali, belum ada tindak lanjut untuk bisa memberdayakan santri. Karena bagaimanapun juga penyelesaian masalah sampah

${ }^{14}$ Zainal dan Sujak, Pancuan dan Aplikasi Pendidikan Karakter, (Bandung: Yrama Widya, 2011), hlm., 2 
harus mampu melibatkan dan memberdayakan santri secara menyeluruh terkait dengan, pembatasan timbunan sampah, pengumpulan sampah, pemilahan sampah, memanfaatan sekaligus mendaurulangan sampah secara berkelanjutan.

Penanganan dan pengelolaan sampah yang benar saat ini sudah sangat penting untuk dilakukan. Pondok Pesantren saat ini sudah seharusnya menjadi tempat untuk belajar tentang pengelolaan sampah yang benar, dengan memulai membangun kesadaran akan penanganan dan pengelolaan sampah.

Yayasan Pondok Pesantren Ibnu Sina memiliki santri yang juga menjadi siswa di SMK Ibnu Sina, maka kegiatan Penguatan Penyelenggaraan Pendidikan Inovatif Dan Kreatifitas Santri Melalui Pembentukan Bank Sampah Berbasis Pesantren Di laksanakan di SMK Ibnu Sina Genteng Banyuwangi yang menurut pengasuh akan lebih bermanfaat karena siswa-siswi SMK Ibnu Sina juga berasal dari bukan santri artinya siswa berasal dari masyarakat yang tinggal disekitar pondok pesantren. Dari jumlah siswa SMK Ibnu Sina 373, kurang lebih 40\% merupakan santri PP Ibnu Sina.

Siswa-siswi SMK Ibnu Sina pada dasarnya telah memahami arti tentang kebersihan lingkungan di buktikan dengan jawaban-jawaban yang disampaikan di Pretest dan posttest saat kegiatan sosialisasi dan pelatihan pengelolaan sampah dengan membentuk bank sampah. Namun masih kurang penerapan pada kebiasaan sehari-hari. Masih adanya sampah berserakan, dan tempat sampah yang kurang layak.

Menurut salah satu guru SMK Ibnu Sina pada keseharian dari siswa maupun siswi mereka diberikan kewajiban piket kebersihan kelasnya masing-masing. Dan keseharian di SMK Ibnu Sina kebersihan lingkungan diberikan tanggung jawabnya pada seorang tukang kebun.

Di SMK Ibnu Sina memiliki jadwal harian, setiap pagi sebelum masuk kelas, akan dilaksanakan sholat dhuha dan siang dilaksanakan sholat dhuhur berjama'ah. Dan teras kelas setiap harinya harus disucikan karena digunakan Sholat dhuha dan dhuhur berjama'ah.

Kebiasaan keseharian dari siswa-siswi SMK Ibnu Sina saat sholat dhuha berjama'ah akan mendapatkan wejangan dari Kepala Sekolah ataupun dari guru-guru. Dan materi yang disampaikan tentang pendidikan karakter dan kebangsaan. Salah satu pendidikan karakter dari siswa yang mesti ditanamkan adalah kecintaan lingkungan yang bersih agar pembelajaran disekolah dapat berjalan kondusif, dan menyenangkan. Selain penanaman kecintaan lingkungan bersih disekolah diharapkan karakter tersebut akan terbawa sampai dikehidupan setelah lulus sekolah, dan akan lebih baik jika karakter cinta lingkungan bersih tertanam dan mampu diapresiasikan saat sampai dikehidupan pada lingkungan masyarakatnya.

Perintisan pembentukan bank sampah di SMK Ibnu Sina selain penanaman kecintaan lingkungan bersih disekolah maupun di masyarakat, juga ada harapan untuk meningkatkan pembelajaran yang inovatif serta kreatifitas siswa dan siswi disekolah.

\section{c. Follow up}

Pengabdian yang telah dilaksanakan di Pondok Pesantren Ibnu Sina tepatnya di SMK Ibnu Sina memiliki harapan untuk mampu menanamkan sikap karakter cinta lingkungan bersih dan meningkatkan kreatifitas siswa dengan melakukan pembentukan bank sampah disekolah. Namun dikarenakan keterbatasan waktu dan dana, tidak lanjut dan monitoring dari kegiatan pengabdian ini akan dilanjutkan oleh Bank Sampah Darussalam dibawah naungan 
Lembaga Penelitian dan Pengabdian Masyarakat Institut Agama Islam Darussalam Blokagung Banyuwangi.

\section{KESIMPULAN}

Indonesia telah memiliki peraturan pemerintah tentang Kebersihan lingkungan serta Peraturan Pemerintah Republik Indonesia Nomor 81 Tahun 2012 Tentang Pengelolaan Sampah Rumah Tangga Dan Sampah Sejenis Sampah Rumah Tangga. Namun pada kenyataannya penerapan kebersihan lingkungan dari sampah masih harus disosialisasikan, dari sinilah ide pengabdian kepada masyarakat berbasis Pondok pesantren ini berasal. Pondok Pesantren sebagai lembaga pendidikan yang memiliki ciri khas mengharuskan seorang siswa bermukim dan belajar penuh berada dilingkungan untuk hidup bersama-sama dengan banyak santri, seringkali menjadi tempat yang kurang mendapat perhatian akan kebersihannya. Maka program pengabdian kepada masyarakat berbasis Pesantren yang dilakukan di PP Ibnu Sina dengan tema Penguatan Penyelenggaraan Pendidikan Inovatif Dan Kreatifitas Santri Melalui Pembentukan Bank Sampah dilaksanakan di SMK Ibnu Sina Genteng Banyuwangi. SMK Ibnu Sina dibawah naungan PP Ibnu Sina yang berdiri 9 Juni tahun 2013 telah melaksanakan sosialisasi dan pelatihan pengelolaan sampah dengan pembentukan bank sampah sekaligus pelatihan pembuatan kompos dari sampah organik dan pembuatan kerajinan dengan pemanfaatan sampah non organik untuk di buat tas, bros dan lain sebagainya. Selanjutnya juga telah dibentuk kader untuk dapat melanjutkan perintisan pendirian bank sampah. Dan dikarenakan keterbatasan waktu dan dana maka untuk menindaklanjuti kegiatan pengabdian tersebut akan dilanjutkan oleh Bank Sampah Darussalam Blokagung Banyuwangi,

\section{REFERENSI}

Adhim, Mohammad Fauzi, 2006, Postitive Parenting: Cara-cara Islami Mengembangkan Karakter Positif pada Anak Anda, Bandung: Mizana.

Alex S, Sukses Mengolah Sampah Organik Menjadi Pupuk Organik, Yogyakarta: Pustaka Baru Press

Bandura, 1977, Social Learning Theory, (Prentice Hall Inc., Englewood Cliffs, New Jersey).

Bimo, Walgito, 1999, Psikologi Sosial (Suatu Pengantar), Yogyakarta: Andi.

Damanhuri, Enri dan Padmi, Tri, Teknologi Pengelolaan Sampah, Bandung: Penerbit ITB.

Depdiknas, 2002. Pengembangan Pelaksanaan Broad-Based Education, High-Based Education, dan Life Skills di SMU. Jakarta: Depdiknas.

E. Colink, 1996, Istilah Lingkungan Untuk Manajemen

Gunarsa, Singgih D. dan Yulia Singgih D Gunarsa, 1991, Psikologi Praktis: Anak, Remaja dan Keluarga, (Jakarta: BPK Gunung Mulia.

Hadi, Achmad Serudji, 2001, "Daur Ulang Barang Bekas sebagai Penopang Sumber Kehidupan”, Laporan Penelitian pada Universitas Indonesia Program Pascasarjana Bidang Ilmu Hukum, Jakarta.

Hambali, Andang dan Q-Anees, Bambang, 2008, Pendidikan Karakter Berbasis Al-Qur'an, Bandung: Simbiosa Pekatama Media. 
Ilham, "Konsep dan Arah Pengembangan Siswa Pecinta Lingkungan Hidup", dalam http://illangtanete84.blogspot.com/, diakses 24 Desember 2016.

Kamus Besar Bahasa Indonesia (KBBI) Online, versi 1.3

Karakteristik sampah plastik, diakses pada 02 Oktober 2014 pukul 21:42 WIB melalui http://jujubandung.wordpress.com.

Kesuma, Dharma dkk., 2011, Pendidikan Karakter: Kajian Teori dan Praktik di Sekolah, Bandung: Remaja Rosdakarya.

M. Djumarsjah, 2008, Filsafat Pendidikan, Malang: Bayumedia Publishing.

M. Idris dan Sujak, 2010, Kamus MIPA, Yogyakarta: Ar-Ruzz Media.

Misbahul Ulum, dkk, "Pengertian Sampah", dalam suisyanto (ed), "Model-Model Kesejahteraan Sosial Islam”, (Yogyakarta: Fakultas Dakwah UIN Sunan Kalijaga Yogyakarta bekerjasama dengan IISEP-CIDA, 2007), cet. 1.

Neolaka, Amos, 2008, Kesadaran Lingkungan, Jakarta: Rineka Cipta.

Peraturan Pemerintah Republik Indonesia Nomor 81 Tahun 2012 Tentang Pengelolaan Sampah Rumah Tangga Dan Sampah Sejenis Sampah Rumah Tangga

Permadi, A. Guruh, 2011, Menyulap Sampah Jadi Rupiah, Surabaya: Mumtaz Media.

Purbasari, Nurul, 2014, Skripsi, Pemberdayaan Masyarakat Melalui Kegiatan Daur Ulang Sampah Plastik (Studi Kasus Pada Komunitas Bank Sampah POKLILI Perumahan Griya Lembah Depok Kecamatan Sukmajaya Kota Depok)

Pusat Bahasa Departemen Pendidikan Nasional, Kamus Besar Bahasa Indonesia, Edisi ke-III.

S. Hadiwiyoto, 1983, Penanganan dan Pemanfaatan Sampah, Jakarta: Yayasan Idayu.

Samani, Muclas dan Hariyanto, 2001, Konsep dan Model Pendidikan Karakter, (Bandung: Remaja Rosda Karya.

Santoso, Nurman, 1990, Pendidikan di Indonesia, (Dari Masa ke Masa), Jakarta: Haji Masagung. Suar, Etrizal, 1996, "Pengaruh Sampah Plastik Terhadap Pengelolaan Lingkungan Hidup di DKI Jakarta”, Laporan Penelitian pada Universitas Indonesia Program Pascasarjana Bidang Ilmu Hukum, Jakarta.

Subekti, Sri, Pengelolaan Sampah Rumah Tangga 3R Berbasis Masyarakat Pendahuluan, Available at: http://www.scribd.com/doc/19229978/tulisan-bektihadini Diakses 27 Desember 2016.

Sumantri, Endang, 2003,Resum Perkuliahan Filsafat Nilai dan Moral, (Bandung: Pascasarjana UPI.

Sunarti, Euis, 2005, Menggali Kekuatan Cinta, Jakarta: Elex Media Komputindo.

Sustiyono, Aris dan Kurdiyono, Studi Tingkat Kesadaran Masyarakat Kota Yogyakarta Terhadap Kelestarian Lingkungan Hidup, http://www.jogjakarta.go.id/app/modules/ banner/images/1222102800.volume2.pdf. diakses tanggal 24 Desember 2016.

Sutidja, Trim, 2001,Daur Ulang Sampah, Bumi Aksara.

Tchobanoglous, 1993, Integrated Solid Waste Management. Mc. Grw Hill: Kogakusha.

Tim Dosen FIP-IKIP, 2003, Pengangtar Dasar-dasar Kependidikan, Surabaya: Usana Offset Printing.

Trim Sutidja, 2001, Daur Ulang Sampah, Bumi Aksara, cet-2.

Undang-Undang Republik Indonesia No. 20 Tahun 2003 Tentang Sistim Pendidikan Nasional (Sisdiknas), (Yogyakarta: Pustaka Pelajar, 2007) 


\section{ENGAGEMENT}

Jurnal Pengabdian Kepada Masyarakat

ISSN : 2579-8375 (Print)

ISSN : 2579-8391 (Online)
This work is licensed under a Creative Commons

Attribution-ShareAlike 4.0 International License.

Wajdi, M Barid Nizarudin. "HARMONISASI NILAI PENDIDIKAN ISLAM DENGAN KEARIFAN BUDAYA LOKAL.” Jurnal Studi Islam: Pancawahana 11, no. 1 (2016): 51-78.

Wajdi, Muh. Barid Nizarudin. "Nyadranan, Bentuk Akulturasi Islam Dengan Budaya Jawa (Fenomena Sosial Keagamaan Nyadranan Di Daerah Baron Kabupaten Nganjuk)."

JURNAL LENTERA : Kajian Keagamaan, Keilmuan dan Teknologi 3, no. 2 (October 13, 2017). Accessed October 2017.

http://www.ejournal.staimnglawak.ac.id/index.php/lentera/article/view/60.

Wibisono, Anatomi dan Profil Konglomerat Bisnis Indonesia.

Wintoko, Bambang, Panduan Praktis Mendirikan Bank Sampah, (Yogyakarta: Pustaka Baru Press) cet-1,

Zainal dan Sujak, 2011, Pancuan dan Aplikasi Pendidikan Karakter, Bandung: Yrama Widya.

Zubaedi, 2011, Desain Pendidikan Karakter: Konsepsi dan Aplikasi dalam Dunia Pendidikan, Jakarta: Kencana.

Zulkifli, Arif, 2014, Dasar-Dasar Ilmu Lingkungan, Jakarta: Salemba Teknika.

(http://smacepiring.wordpress.com/2008/02/19/pendekatan-dan-metode-pembelajaran/).

Diakses pada tanggal 7 januari 2017. 